\title{
A rat pancreatic ribonuclease fused to a late cotton pollen promoter severely reduces pollen viability in tobacco plants
}

\author{
R.B. Bernd-Souza ${ }^{1}$, M.F. Grossi de Sa ${ }^{1}$, D.D. Ellis ${ }^{2}$ and B.H. McCown ${ }^{2}$
}

\begin{abstract}
The effects of an animal RNase fused to the late cotton pollen-specific promoter $G 9$ in a plant system were investigated. Expression of the chimeric genes G9-uidA and G9-RNase in tobacco plants showed that the 1.2-kb promoter fragment of the G9 gene was sufficient to maintain tissue and temporal specificity in a heterologous system. GUS (beta-glucuronidase) expression was detected only in pollen from anther stage 6 through anthesis, with maximal GUS activity in pollen from stage 10 anthers. Investigating the effects of the rat RNase on pollen viability at stage 10 , we found that pollen viability was reduced from 79 to $8 \%$ and from 89 to $40 \%$, in pollen germination and fluoresceine diacetate assays, respectively, in one G9-RNase transgenic line, suggesting a lethal effect of the RNase gene. This indicates that the rat RNase produces deleterious effects in this plant system and may be useful for engineering male sterility.
\end{abstract}

\section{INTRODUCTION}

The use of genetic cell ablation through the expression of RNases, toxic genes or antisense mRNA along with promoters directing the expression to different cell types has aided in the molecular dissection of plant developmental processes. The cell ablation techniques have been used to study male gametogenesis, by visualization of the developmental events in the absence of specific cells, and can be used as a tool to produce male sterility (Mariani et al., 1990; McCormick, 1991; Nasrallah et al., 1991; Denis et al., 1993; Goldberg et al., 1993; Roberts et al., 1995; Twell, 1995; Zhan et al., 1996; Beals and Goldberg, 1997).

Male gametogenesis occurs in the sporophytic tissue of the anther and begins with the meiotic division of a diploid sporogenic cell (pollen mother cell) into a tetrad of haploid microspores, which later undergo an asymmetric mitotic division, resulting in pollen grains. These pollen grains contain a small generative cell within a larger vegetative cell. The pollen grains mature and undergo another mitotic division, before or after germination, giving rise to two sperm cells that complete the process with the double fertilization of the egg and the central cell (Bedinger, 1992; McCormick, 1993).

The genes expressed during male gametogenesis have been classified as "early" genes, which become active soon after meiosis is complete, or as "late" genes, when become active after microspore mitosis (Mascarenhas, 1990). About $75 \%$ of the mRNAs present in mature pollen of Tradescantia occur in two or more abundant classes, compared to only $35 \%$ of mRNAs in shoots (Mascarenhas, 1988). This, and the fact that the late pollen-specific cotton gene $G 9$ was isolated by differential screening (John and Petersen,
1994), make it probable that $G 9$ is a high-abundance transcript (Scott et al., 1991). Thus, the 5' flanking region of the $G 9$ gene can promote pollen-specific expression, certainly at levels high enough for cell ablation. The native $G 9$ gene shows maximal expression on the day of anthesis (John and Petersen, 1994), when there is an existing stored pool of presynthesized RNAs (mRNA, rRNA and tRNA) that will be used for protein translation during pollen germination (Mascarenhas, 1988; Clarke and Newbigin, 1993). It indicates that $G 9$ is an adequate promoter to monitor the efficacy of an RNase gene. If the RNase gene works properly in the plant system, it may cause a reduction in pollen germination by depletion of protein synthesis.

The RNases used to investigate the role of specific anther genes/tissues and to induce male sterility have fungal or bacterial origin (Mariani et al., 1990; Denis et al., 1993; Roberts et al., 1995; Zhan et al., 1996; Beals and Goldberg, 1997), and were reported to present thermoinstability (Denis et al., 1993). We investigated the effects on male gametogenesis and pollen viability, of an animal RNase fused to the $G 9$ cotton pollen promoter, and the possibility of using this system to generate male sterility.

\section{MATERIAL AND METHODS}

\section{Agrobacterium tumefaciens vectors}

Two A. tumefaciens LBA4404 binary vectors were obtained from Agracetus, Inc. (Middleton, WI, USA). Both vectors contained the neomycin phosphotransferase (NPTII) selection gene and $1.2 \mathrm{~kb}$ of the $G 9$ cotton gene promoter (accession number U09805; John and Petersen, 
1994) within the T-DNA regions. The $G 9$ promoter fragments were linked to different coding regions in the two vectors, one to a rat pancreatic RNase gene (accession number J00771) in plasmid TV4G9pRNaseA (G9-RNase), and the other to a uidA gene (Jefferson, 1987) in plasmid TV4p2119G9P (G9-GUS).

\section{Plant transformation}

Aseptically grown immature leaves of Nicotiana tabacum 'Havana 425' were cut into squares $(2 \mathrm{~cm} \times 2$ $\mathrm{cm}$ ), and placed in MSH medium (Murashige and Skoog, 1962, $0.1 \mathrm{mg} \mathrm{NAA} / 1,1.0 \mathrm{mg}$ benzyladenine/l, $7 \mathrm{~g}$ agar/l) for $24 \mathrm{~h}$. Leaf discs were transferred to $15-\mathrm{ml}$ centrifuge tubes, inoculated with an overnight culture of A. tumefaciens diluted $1 / 5\left(\mathrm{OD}_{550} \sim 0.6\right)$, and vortex mixed on high for 15 $20 \mathrm{~s}$. The liquid was removed and the discs blotted dry and placed on Whatman filter paper on Petri plates containing MSH broth over a feeder tobacco cell culture (maintained in MS medium containing $2 \mathrm{mg}$ 2,4-D/l) for three days. The discs were then transferred to MSHA selective medium (MSH supplemented with $500 \mathrm{mg}$ carbenicillin/l, $250 \mathrm{mg}$ cefotaxime/l and $100 \mathrm{mg}$ kanamycin/l) and subcultured onto the same medium every seven days until callus and/or bud formation ( 2-3 weeks). Calli and shoot buds were excised from the discs and individually subcultured in MSHA without cefotaxime for 3-4 weeks until the buds were elongated enough to root on hormone-free MS0 selective medium (MSH without hormones and supplemented with $500 \mathrm{mg}$ carbenicillin/l and $100 \mathrm{mg}$ kanamycin/l). Rooting occurred after 1-3 weeks, at which time the plants were acclimated to a lower humidity and transferred to soil. The studies were performed with primary transformants $\left(\mathrm{T}_{0}\right)$.

\section{Genomic DNA isolation}

Total DNA was prepared from young leaves as follows: two leaf discs ( $2 \mathrm{~cm}$ in diameter) were placed in a 1.5-ml Eppendorf tube with $50 \mu \mathrm{l}$ of sand (white quartz, 50-70 mesh, Sigma S-9887) and freeze-dried in liquid nitrogen for at least $30 \mathrm{~s}$. Five hundred microliters of prewarmed $\left(60^{\circ} \mathrm{C}\right)$ isolation buffer $(2 \%(\mathrm{w} / \mathrm{v})$ hexadecyltrimethylammonium bromide, $1.4 \mathrm{M} \mathrm{NaCl}, 0.2 \%(\mathrm{v} / \mathrm{v}) \beta$ mercaptoethanol, $20 \mathrm{mM}$ EDTA, $100 \mathrm{mM}$ Tris- $\mathrm{HCl}, \mathrm{pH}$ 8.0) was then added to the tube, and ground (American model LR - 41 A stirrer). After 30-min incubation at $60^{\circ} \mathrm{C}$ with occasional swirling, $500 \mu \mathrm{l}$ of chloroform-isoamyl alcohol $(24: 1 \mathrm{v} / \mathrm{v})$ was added to each tube, the contents of which were then mixed by inverting the tube 10-15 times. The tubes were centrifuged for $20 \mathrm{~s}$ and the supernatant (aqueous phase) was then transferred to a clean tube prior to the addition of $2 / 3$ total volume cold isopropanol. The nucleic acids precipitated as a white cloud, which was removed with a glass hook and transferred to $1 \mathrm{ml}$ of wash buffer (76\% v/v ethanol and $10 \mathrm{mM}$ ammonium acetate). The washing was repeated and the samples then centrifuged before air-drying. The pellet was resuspended in $100 \mu$ of TE buffer (10 mM Tris-HCl, pH 7.4, and $1 \mathrm{mM}$ EDTA) containing RNase A at a final concentration of $100 \mu \mathrm{g} / \mathrm{ml}$. The amount of DNA was estimated by fluorometry.

\section{PCR and Southern blots}

PCR reactions were performed in 0.6-ml siliconized reaction tubes (Slickseal) in a Perkin/Elmer PCR cycler. The PCR mix tube contained 50-500 ng genomic DNA (or 1-100 pg of plasmid DNA), $2 \mathrm{mM}$ dNTPs, $0.5 \mathrm{M} \mathrm{KCl}$, $100 \mathrm{mM}$ Tris, $\mathrm{pH} 8,16 \mathrm{mM} \mathrm{MgCl}_{2}, 10 \mathrm{mM}$ of each primer (3'and 5'), and 4.5 units Taq polymerase/ $\mu$ (Promega) overlain with 1-2 drops of mineral oil. The PCR reaction consisted of 30 cycles of $60 \mathrm{~s}$ at $96^{\circ} \mathrm{C}, 45 \mathrm{~s}$ at $55^{\circ} \mathrm{C}, 60 \mathrm{~s}$ at $72^{\circ} \mathrm{C}$, followed by a 3 -min hold at $72^{\circ} \mathrm{C}$ and a continuous hold at $4^{\circ} \mathrm{C}$. The primers for uidA gene (DR 37/48) and RNase gene (MEJ100/101) amplifications were furnished by Agracetus, Inc.

Ten micrograms of genomic DNA was digested with appropriate restriction enzymes (BamHI and $X b a \mathrm{I})$, and samples were electrophoresed on a $1 \%$ agarose gel. DNA was transferred to nylon membranes (Hybond N, Amersham) prior to hybridization using $\left[{ }^{32} \mathrm{P}\right]$ probes amplified by $\mathrm{PCR}$ and labeled by random priming (Ready-to-Go kit, Pharmacia Biotech). The hybridization conditions were $5 \mathrm{X}$ SSPE, 5X Denhart's solution, $0.5 \%$ SDS and $50 \mu \mathrm{g}$ salmon sperm DNA $/ \mu \mathrm{l}$, at $65^{\circ} \mathrm{C}$, overnight. The membranes were washed once (30 $\mathrm{min})$ at room temperature with $2 \mathrm{X} \mathrm{SSPE}$ containing $0.1 \%$ SDS, once with $1 \mathrm{X}$ SSPE containing $0.1 \%$ SDS as above and once at $65^{\circ} \mathrm{C}$ for $1 \mathrm{~h}$ with $0.5 \mathrm{X} \mathrm{SSPE}$ containing $0.1 \%$ SDS. The membranes were then autoradiographed at $-80^{\circ} \mathrm{C}$ with intensifying screens.

\section{GUS and MUG assays}

The histochemical staining for beta-glucuronidase (GUS) and the fluorogenic enzymatic assay for 4-methyl umbelliferyl beta-D-glucuronide (MUG) were adapted from Jefferson (1987). For histochemical examination, manually cut transverse sections from anthers and ovaries, pieces of leaves, petals, sepals, shoots, roots, and pollen grains were examined for GUS expression. The plant material was incubated in sodium phosphate buffer (100 mM NaH${ }_{2} \mathrm{PO}_{4} \cdot \mathrm{H}_{2} \mathrm{O}, \mathrm{pH} 7.0,10 \mathrm{mM} \mathrm{Na} 2$ EDTA, 0.1\% Triton X-100), containing freshly prepared 5-bromo-4chloro-3-indoyl glucuronide (X-gluc; $0.5 \mathrm{mg} / \mathrm{ml}$ ) dissolved in DMSO. The stained sections and pollen grains were examined using a stereo microscope.

For the MUG assays, one flower of each anther developmental stage was used. The flowers were placed on ice immediately after collection and then transferred to Eppendorf tubes with $125 \mu \mathrm{l}$ of lysis buffer $(50 \mathrm{mM}$ $\mathrm{Na}_{2} \mathrm{HPO}_{4}, 10 \mathrm{mM}$ NaEDTA, $10 \mathrm{mM} \beta$-mercaptoethanol, $0.1 \%$ Triton $\mathrm{X}-100,0.1 \%$ sodium laryl sarcosine, $25 \mu \mathrm{g}$ phenylmethyl-sulfonyl fluoride/ml). The tissue was fully 
ground with a glass pestle (American model LR - 41A stirrer), followed by centrifugation for $3 \mathrm{~min}$. Total protein was quantified using the BCA protein assay reagent (Pierce). To quantify methyl-umbelliferone (MU), $30 \mu \mathrm{l}$ of the supernatant was added to $1 \mathrm{ml}$ pre-warmed $\left(37^{\circ} \mathrm{C}\right)$ assay buffer $(1$ $\mathrm{mM}$ MUG in lysis buffer). Aliquots $(200 \mu \mathrm{l})$ were withdrawn after $15 \mathrm{~min}$, added to $800 \mu \mathrm{l}$ stop buffer $\left(0.2 \mathrm{M} \mathrm{Na}_{2} \mathrm{CO}_{3}\right.$ in $\mathrm{H}_{2} \mathrm{O}$ ), and vortexed. The resulting fluorescence was read in a fluorometer (model TKO100, Hoefer Scientific Instruments), with excitation at $365 \mathrm{~nm}$ and emission at $455 \mathrm{~nm}$. The assays were done at least three times.

\section{Pollen viability assays}

The anther developmental stages were classified as described by Koltunow et al. (1990). Pollen germinability was evaluated by excising the anthers from a flower of each developmental stage and dividing the anthers into two samples to evaluate germination viability. Anthers were cut with a scalpel and pollen grains gently squeezed into an Eppendorf tube containing $500 \mu \mathrm{l}$ of liquid Micro Art's germination medium. The suspension was mixed and immediately poured onto a Petri dish with solid germination medium. The pollen grains were then spread equally over the solid medium. Following incubation in the dark at room temperature for $4 \mathrm{~h}$, the pollen grains were observed with a Nikon Diaphot-TMD inverted microscope and scored as germinated (based on the presence of a pollen tube) or nongerminated. The germination medium consisted of sucrose (150 g), $\mathrm{H}_{3} \mathrm{BO}_{3}(100 \mathrm{mg}), \mathrm{CaNO}_{3}(300 \mathrm{mg}), \mathrm{MnSO}_{4}(100$ $\mathrm{mg}$ ) and $\mathrm{MgSO}_{4}(500 \mathrm{mg})$ per liter of distilled $\mathrm{H}_{2} \mathrm{O}$. For the solid medium, $5 \%$ purified agar was added, heated in a microwave oven and poured on Petri dishes. The medium was used on the day it was prepared.

For fluoresceine diacetate (FDA) staining, the pollen grains were prepared essentially as described above. Five microliters of a stock solution of FDA $(5 \mathrm{mg} / \mathrm{ml} \mathrm{ac}-$ etone) was added to Eppendorf tubes containing $500 \mu \mathrm{l}$ of liquid Micro Art's germination liquid medium with pollen grains. The mixture was incubated for $60 \mathrm{~min}$ in the dark at room temperature. After incubation, a drop of the pollen suspension was placed on a slide with a cover slip and the number of fluorescing pollen grains was determined. The observations were made with a Nikon Diaphot-TMD inverted microscope fitted with a Nikon UV-1A epi-fluorescence filter combination (400 dichroic mirror, 356/ 10 excitation filter, 400 barrier filter). A minimum of 100 pollen grains were counted in each of two samples on three or more occasions.

\section{Histology}

Whole flowers were fixed in CRAF V ( $1 \%$ chromic acid, $10 \%$ acetic acid, $40 \%$ formaldehyde) for $48 \mathrm{~h}$. The anthers were removed, washed in running distilled $\mathrm{H}_{2} \mathrm{O}$ for $24 \mathrm{~h}$ and dehydrated in an alcohol (ethanol and tertiary bu- tyl alcohol) series. After embedding in paraffin, 15- $\mu \mathrm{m} \mathrm{sec-}$ tions were cut, mounted, deparaffinated and stained with safranine and fast green according to Johansen (1940) and Saas (1940), respectively. The sections were examined and photographed by light microscopy.

\section{RESULTS}

\section{G9-GUS tissue expression}

Tobacco plants were transformed with a $1.2-\mathrm{kb}$ promoter fragment from the $G 9$ cotton gene containing 370 bp of the original coding region fused to the GUS reporter gene. The T-DNA used to transform the tobacco plants with the G9-GUS chimeric gene is shown in Figure 1A. The transformed plants were analyzed by PCR to confirm GUS integration (Figure 2), and five transgenic plants were chosen for further analysis. Histochemical GUS assays were performed on stage 2 pollen grains when microspores separated from the tetrad, through anthesis, as well as on sections of the anther, ovary and nonreproductive cells

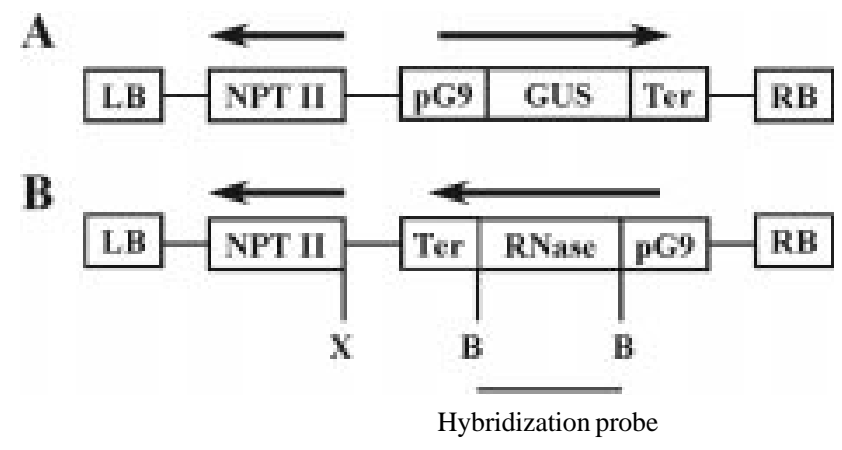

Figure 1 - Diagram of the T-DNA region of the Agrobacterium tumefaciens vectors used for tobacco transformation. The vectors contained the chimeric genes 69 -GUS ( $G 9$ promoter fused to GUS reporter gene) (A) or $G 9$ RNase ( $G^{9}$ promoter fused to the rat RNase coding region) (B). The sites for the restriction endonucleases BamHI (B) and XbaI (X) and the DNA fragment used as the hybridization probe in Southern blots are shown Neomycin phosphotransferase (NPTII) was used as a marker. LB, RB, TDNA left and right borders, respectively.

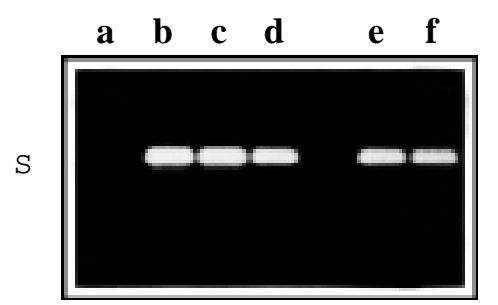

Figure 2 - Polymerase chain reaction gel of tobacco clones transformed with G9-GUS. Lanes a, Non-transformed plant, negative control; b-f, GUSpositive transgenic clones. The arrowhead shows a 710-bp fragment amplified with the GUS primers (DR 37/48) furnished by Agracetus Inc. 
from flowers, leaves, shoots and roots. Blue staining indicative of GUS activity was seen only in pollen and not in the cells of other tissues (Figure 3). GUS activity was detected as early as stage 6 , when there are still remnants of a degenerated tapetum, and in subsequent stages through anthesis. These results demonstrate that the $1.2-\mathrm{kb}$ promoter fragment is sufficient to direct pollen specific expression. In addition, enzymatic assays (MUG) were done with a transformed clone and a nontransformed tobacco plant (Figure 4). The peak expression of the reporter gene in tobacco occurred at stage 10, when the flower begins to open, and contrasted with the maximal mRNA concentration of the original $G 9$ gene in cotton found at the day of anthesis (John and Petersen, 1994).

\section{Generation of G9-RNase transgenic plants and T-DNA insert numbers}

The T-DNA used to transform the tobacco plants with the G9-RNase chimeric gene is shown in Figure 1B. Total DNA from five of the $\mathrm{Kan}^{\mathrm{r}}$ transformed tobacco clones was digested with BamHI, generating an RNase internal fragment. A Southern blot probed with a 700-bp PCR-amplified internal fragment of the RNase coding region (Figure 5A) confirmed integration of the RNase gene into the plant genome. Nuclear DNA from the five G9-RNase transgenic tobacco clones was digested with $X b a \mathrm{I}$, which has a single cleavage site in the T-DNA region, providing T-DNA/plant genome fragments of dif-
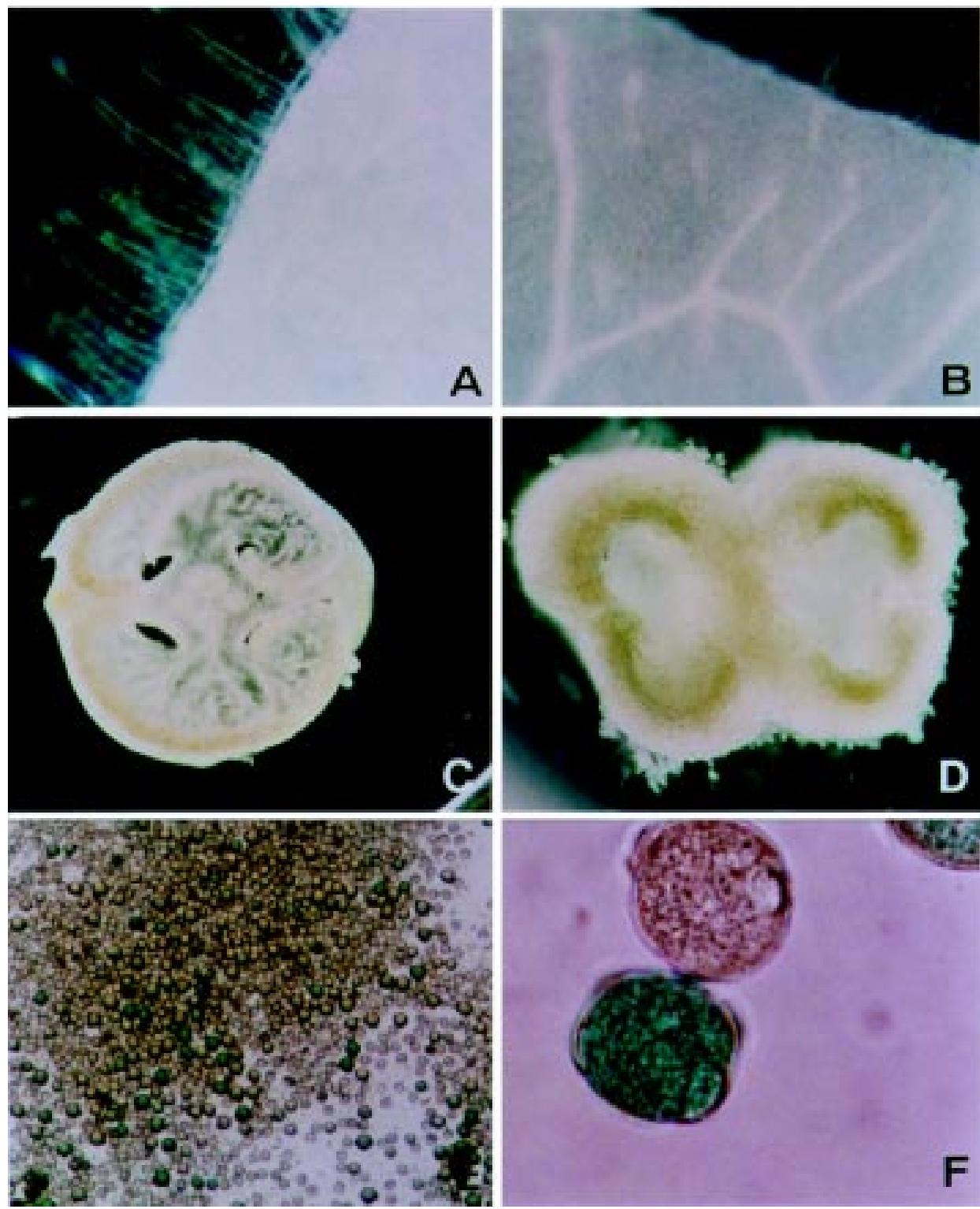

Figure 3 - Histochemical GUS assays of different plant organs in G9-GUS transgenic tobacco at anther stage 10. A, Leaf; B, petal; $\mathbf{C}$, ovary; $\mathbf{D}$, anther with blue-colored microspores; $\mathbf{E , F}$, mature pollen grains. 


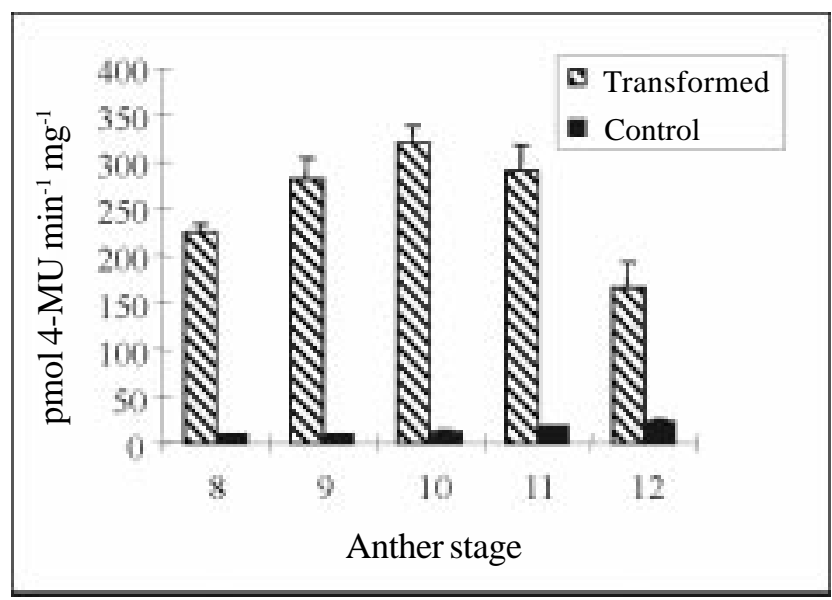

Figure 4 - Temporal pattern of $G 9$-GUS expression, measured by the MUG fluorogenic assay in tobacco anthers at stages 8-12. The control is a nontransformed Nicotiana tabacum 'Havana 425' plant. The product of GUS enzyme activity (MU) was quantified with a fluorimeter with excitation at $365 \mathrm{~nm}$ and emission at $455 \mathrm{~nm}$. The results are the average of at least three independent measurements.

$\mathbf{A}$

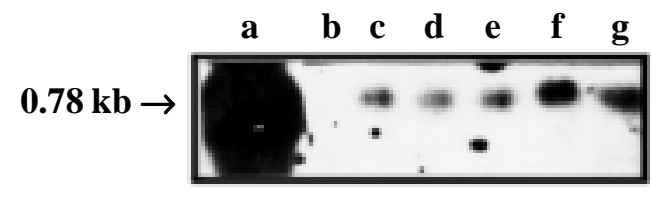

B

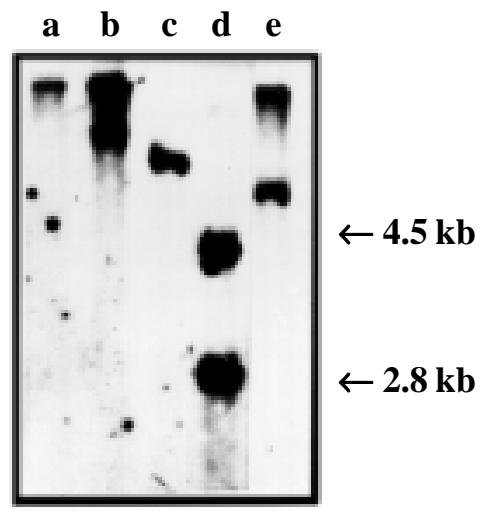

Figure 5 - Autoradiographs of Southern blots of genomic DNA extracted from G9-RNase-transformed tobacco plants and digested with restriction endonucleases. A, BamHI, providing an RNase internal fragment; lanes a, plasmid positive control; $\mathbf{b}$, nontransformed plant, negative control, and c-g, transgenic clones $R N 1-5$, respectively; B, XbaI, providing T-DNA/plant DNA border fragments which reflect the number of T-DNA loci in each plant; lanes a-e, transgenic clones $R N 1-R N 5$, respectively. The DNA fragment used as hybridization probe in the Southern blots is indicated as a black bar beneath the restriction enzyme map of the TDNA region in Figure 1B. ferent sizes. A Southern blot probed with the RNase internal fragment (Figure 5B) allowed the detection of the number of copies of the RNase gene. Three of the clones, $R N 2, R N 4$ and $R N 5$, had two insertions of the RNase gene, and two clones, $R N 1$ and $R N 3$, had only one insertion.

\section{Pollen grain germination}

To study the effect of the rat RNase gene on pollen viability, the germinability and fluoresceine diacetate staining tests were performed on anther stage 10 pollen, when the $G 9$ promoter confers maximal expression (as shown with 69 -GUS transgenic tobacco). Three transformed clones (RN2-RN4) were compared morphologically to wild type tobacco. Whenever germination occurred, the pollen tube growth was similar (equivalent length and rate) to the nontransformed pollen grains (Figure 6A). On average, $79 \%$ of the nontransformed tobacco pollen grains germinated on the artificial medium (Figure 7A). All transformed clones had an average pollen germination which was lower than the wild type control. Clone $R N 3$, which had only one copy of RNase, had a pollen viability (72\%) close to the control value, whereas the clones $R N 2$ and $R N 4$, with two copies of the RNase gene, had significantly less pollen germination (55 and 8\%, respectively).

\section{FDA test}

The degradation of FDA by intracellular esterases yields fluoresceine, which can be visualized under ultra-violet light (Figure 6B). FDA degradation was examined using four transformed clones, two of them, RN4 and RN5, containing two copies of the RNase gene, and two, RNI and $R N 3$, containing one copy of the RNase gene. Independent of the number of insert copies, three transgenic clones, $R N 1$, $R N 3$ and $R N 5$, showed no significant difference from the non-transformed control (Figure 7B). The clone with the least pollen germination, $R N 4$, also showed a much lower percentage of pollen viability (40\%) in this test than did the non-transformed control (89\%). This clone was chosen for morphological studies.

\section{Phenotype of a G9-RNase-transformed clone}

Macroscopically (naked eye observations), the transformed clone $R N 4$ had a vegetative and floral appearance that was indistinguishable from nontransformed plants. The flowers showed normal development, with pistil, stamens and pollen shedding similar to the control plants (Figure 8A).

Microscopically (light microscopy), the pattern of anther development and the aspect of its tissues in the transformed clone also resembled the wild type, with the tapetum degeneration being analogous (Figure 8B-D). The pollen grains were morphologically similar in size and shape, with comparable patterns of staining in the nucleus, cytoplasm, and exine. 

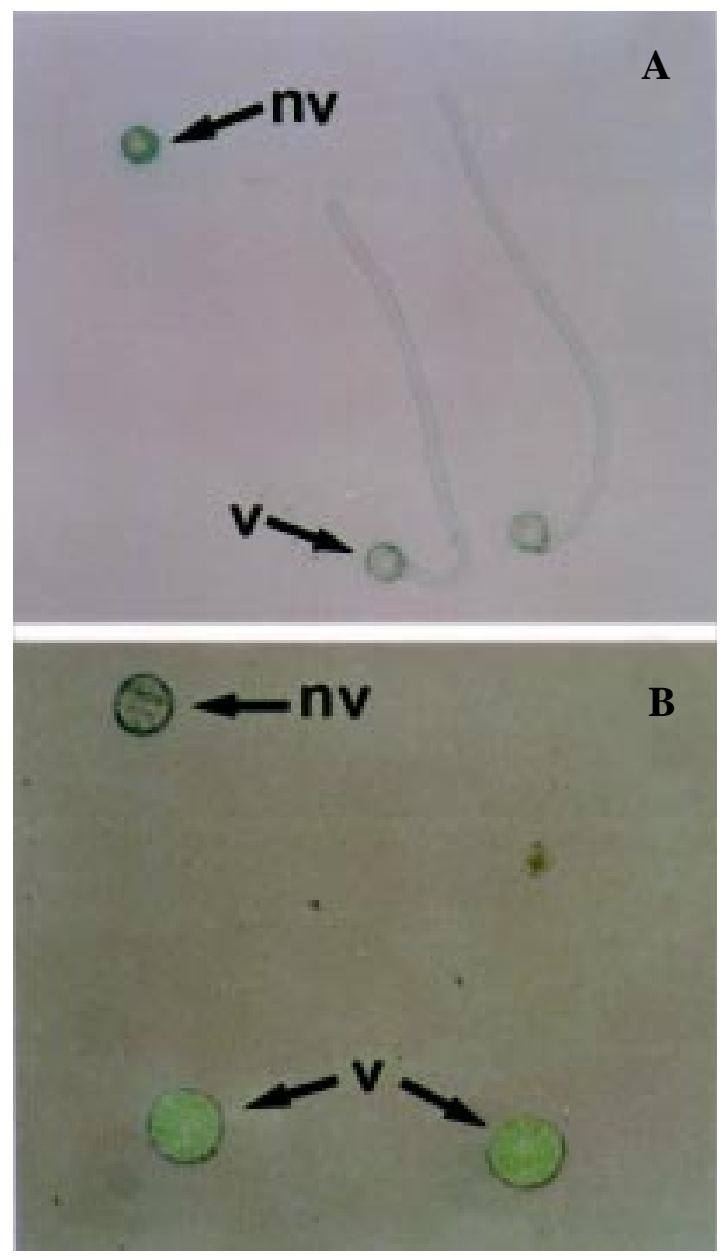

Figure 6 - Phenotype of mature pollen grains of the transgenic tobacco clone $R N 4$ under light microscopy. A, Germination test. Arrows show a viable (v) germinated pollen grain (emitting pollen tube on Micro Art's media), and a nonviable pollen grain (nv). B, FDA test. Arrows show fluorescent viable pollen grains (v) and a nonviable pollen grain (nv).

\section{DISCUSSION}

We investigated the gene expression patterns in tobacco anthers during the developmental stages defined by Koltunow et al. (1990), beginning at stage 1, when all major tissues (epidermis, endothecium, connective, vascular bundle, stomium and tapetum) have differentiated, meiosis is completed, and microspores are bound together as tetrads. From stage 1 to stage 5, the anthers increase in weight and length, and then they maintain their volume relatively constant up to stage 11 , after which they decrease to the next stage (stage 12) when the flower opens fully and the anthers dehisce. The pattern of mRNA synthesis in developing anthers shows tapetal dominance during sporogenesis and early microspore development, in contrast to microspore dominance in later stages of development (Scott et al., 1991).

Differential hybridization, a method widely used for

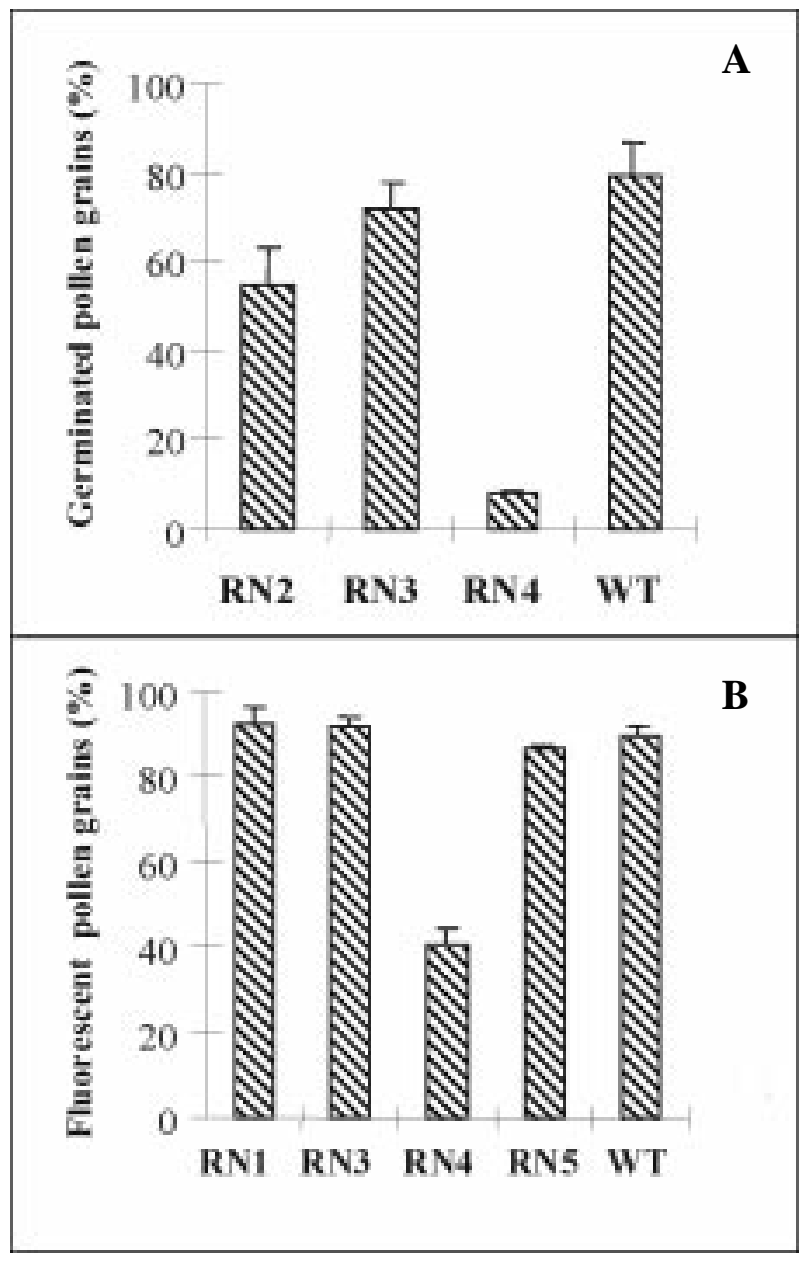

Figure 7 - Viability of G9-RNase transgenic tobacco clones RN1-RN5 and nontransformed Nicotiana tabacum 'Havana 425' (WT) at anther developmental stage 10. A, Percentage of viable pollen grains germinating on Micro Art's media (see Figure 6A). B, Percentage of viable fluorescent pollen grains (see Figure 6B). A minimum of 100 pollen grains were counted per sample, in at least three independent replications.

screening anther-specific genes, favors the isolation of high-abundance transcripts with a bias for tapetum or microspore specificity, depending on the anther developmental stage of the c-DNA library (Scott et al., 1991). The cotton $G 9$ gene is a late microspore-specific gene which shows increasing mRNA accumulation along with pollen maturation, with maximal transcriptional activity on the day of anthesis (John and Petersen, 1994). In tobacco, Schrauwen et al. (1990) showed that immediately after mitosis of the haploid microspore there is a rise in cell activity, which marks a very dynamic period of the pollen developmental process, with an increase of $50 \%$ in the cell dry weight and $300 \%$ in the mRNA content.

In our experiments, the $G 9$ promoter fused to the reporter gene uidA showed maximal expression at stage 10 in transgenic tobacco (Figure 4), coinciding with the transcriptional dynamic period observed by Schrauwen $e t$ al. (1990), but occurring slightly before the peak of ex- 

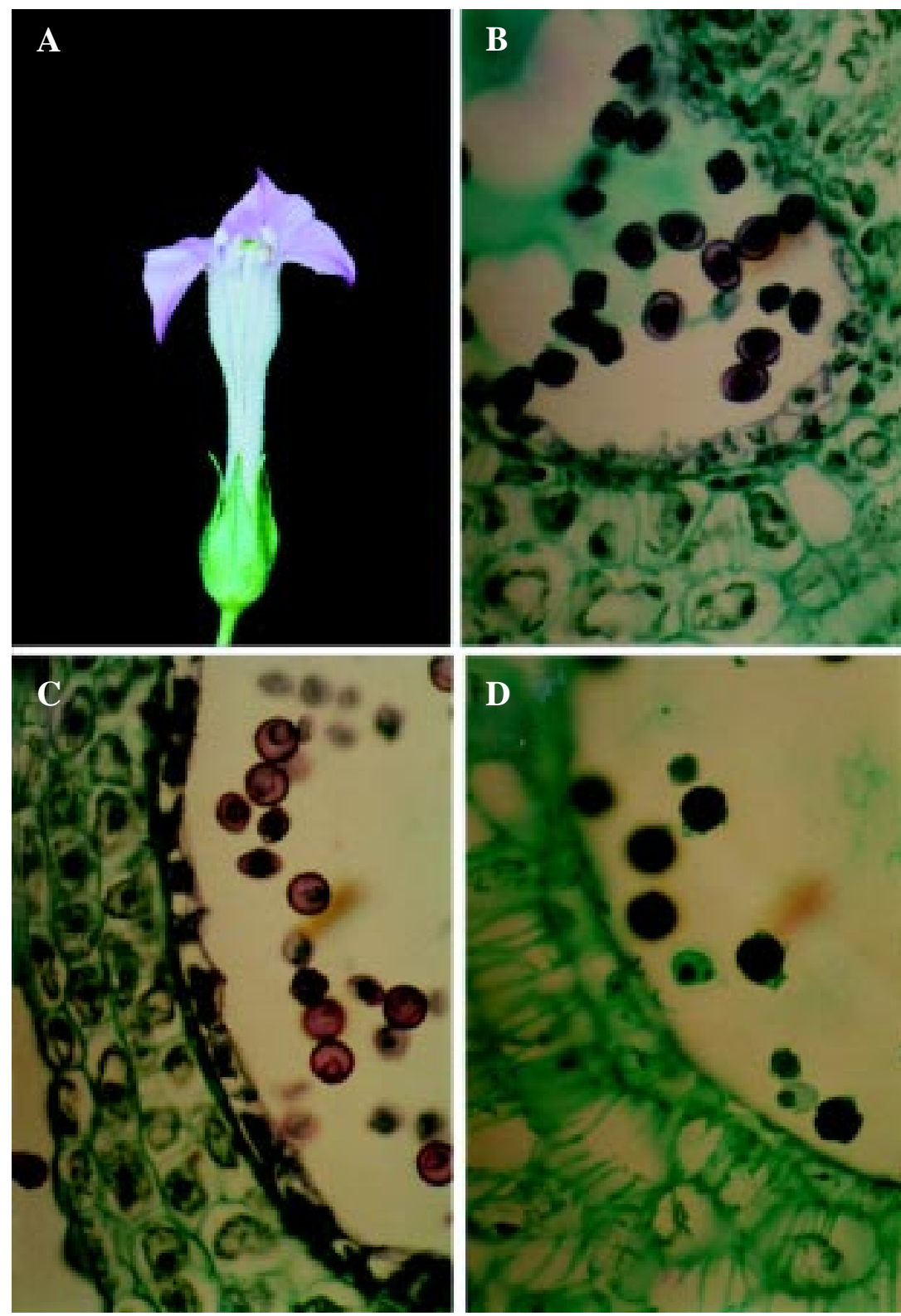

Figure 8 - Floral morphology of the transgenic tobacco clone RN4. A, Flower at anthesis, phenotypically similar to a nontransformed flower. B-D, Anther locula at different developmental stages. Early uninucleate microspores (stage 2), meiosis complete and microspores have separated from tetrad (B); late uninucleate microspores (stage 5) (C); binucleate pollen grains (stage 10) (D). Magnification for B-D, 320X.

pression found for the endogenous cotton $G 9$ gene (John and Petersen, 1994). A similar temporal difference in the expression of a chimeric-GUS construct was also reported by Koltunow et al. (1990) for TA29 in tobacco, where endogenous transcripts are present from anther stages 1 to 6 , with maximal levels at stage 3 . In contrast, when a 279-bp 5' sequence of TA29 was fused to uidA, intense enzyme activity was seen at anther stage 4 , and no blue color was observed in cells of stage 1 and stage 6 anthers of the same transformants. Furthermore, in the last two stages (11 and 12) of development prior to fertilization, the anthers decreased in volume, which might have affected the results of the MUG assays. In spite of the small temporal variance in G9-GUS expression, the $1.2-\mathrm{kb}$ promoter was sufficient to maintain pollen specificity in tobacco, as shown by histochemical staining of the floral and vegetative tissues (Figure 3).

Our studies of the deleterious effect of rat RNase on pollen viability were performed at anther stage 10, since this stage showed a high level of chimeric $G 9$ expression. In addition, the anther volume is stable at this stage and the unopened flower/anther minimizes undesired side effects. Of the various methods for assaying pollen viability (see a list in Trognitz, 1991), we chose pollen germina- 
tion and fluoresceine diacetate staining, as well as morphological observations of whole plants and their anther development. We analyzed five transgenic clones, $R N 1$ $R N 5$, in which RNase integration was confirmed by Southern blots (Figure 5A). Macroscopically, the transformants were indistinguishable from nontransformed plants in that they had a normal vegetative and floral development (Figure 8A), and the amount of pollen shed was similar to the controls. Pollen from transformed (Figure 6) and nontransformed plants was also almost identical in appearance. Histological sections from anther stages 1-12 (Figure 8BD) showed no morphological differences from the control plants, including the pattern of coloration following safranine-fast green staining. However, there were significant differences, in the viability tests, in the quantity of pollen that hydrated but could not germinate or lost metabolic activity.

Three clones ( $R N 2, R N 4$ and $R N 5$ ) had two copies of RNase gene, but only one transgenic clone, $R N 4$, showed a major reduction in pollen viability. It may be that the two copies of the RNase in this clone may have been integrated in a place of the plant genome that promoted high expression. Such position effects have been previously suggested by other authors (Morota and Uchimiya, 1988; Peach and Velten, 1991).

The pollen grains of clone $R N 4$ showed an $8 \%$ germination capacity. A similar case of severely reduced male fertility in tobacco caused by an RNase was found by Zhan et al. (1996) using a promoter of a rice pollen-specific gene ( $P S 1)$ fused to Barnase. Another case of male sterility caused by an RNase was reported by Denis et al. (1993). In neither of these cases were the effects correlated with insert copy number.

The maximal concentration of $G 9$ RNA in clone $R N 4$ pollen may have occurred on the day of anthesis, suggesting a post-anthesis function (John and Petersen, 1994). This is compatible with the function of polygalacturonase in degrading complex carbohydrates found between the cells of the stylar transmitting tract (Scott et al., 1991). On the day of anthesis, however, there is a stored pool of presynthesized mRNAs that are translated during germination (Mascarenhas, 1988). Therefore, the rat RNase gene may not have shown its cytotoxicity on pollen metabolism until the emission of the pollen tube, thereby leading to a severe reduction in pollen viability.

In conclusion, the rat RNase was properly expressed in this plant system and may therefore be useful for engineering male sterility.

\section{ACKNOWLEDGMENTS}

We thank Agracetus, Inc. (Middleton, WI, USA) for providing the engineered Agrobacteria and the PCR primers to carry out this work, and Drs. M.J. Miller and M.E. John for technical discussions. We also thank Dr. S.J. Peloquin (UW-Madison, WI, USA), and his former student Dr. S. Nilmalgoda for greenhouse space and histological advice. We thank Dr. R.D. Vierstra (UW-
Madison, WI, USA) and laboratory staff for allowing us to use their radioactive facilities. We thank Dr. R.A. Serres, and Ms. E.F. Santana, M.V. Coutinho and S.G. Ribeiro for sharing their expertise. This work was part of the Ph.D. thesis of the first author who was funded by the Brazilian Council for Scientific Re$\operatorname{search}(\mathrm{CNPq} / \mathrm{RHAE})$.

\section{RESUMO}

Foram investigados os efeitos da expressão de uma ribonuclease de origem animal em um sistema vegetal, ligando-se esta ao promotor do gene pólen-específico $G 9$ de algodão. Examinouse a expressão dos genes quiméricos G9-uidA e G9-RNase em plantas de tabaco e determinou-se que o fragmento de $1.2 \mathrm{~kb}$ do promotor do gene $G 9$ foi suficiente para manter a especificidade temporal e espacial da expressão, em sistema heterólogo. A expressão do gene GUS foi detectada somente em pólen, do estágio 6 do desenvolvimento da antera até a antese, com atividade máxima em pólen de anteras no estágio 10. Estudos neste estágio com linhagens transgênicas contendo G9-RNase mostraram que um clone transgênico apresentava reduções na viabilidade do pólen de 79 para $8 \%$ e de 89 para $40 \%$ nos testes de germinação e coloração com diacetato de fluoresceína, respectivamente, sugerindo letalidade na expressão do gene de RNase. Estes resultados indicam que a RNase animal apresenta um efeito deletério em planta e oferece possibilidade de uso na obtenção da esterilidade masculina.

\section{REFERENCES}

Beals, T.P. and Goldberg, R.B. (1997). A novel cell ablation strategy blocks tobacco anther dehiscence. Plant Cell 9: 1527-1545.

Bedinger, P. (1992). The remarkable biology of pollen. Plant Cell 4: 879887.

Clarke, A.E. and Newbigin, E. (1993). Molecular aspects of self-incompatibility in flowering plants. Annu. Rev. Genet. 27: 257-279.

Denis, M., Delourme, R., Gourret, J.P., Mariani, C. and Renard, M. (1993). Expression of engineered nuclear male sterility in Brassica napus. Plant Physiol. 101: 1295-1304.

Goldberg, R.B., Beals, T.P. and Sanders, P.M. (1993). Anther development: basic principles and practical applications. Plant Cell 5: 1217-1229.

Jefferson, R.A. (1987). Assaying chimeric genes in plants: the GUS gene fusion system. Plant Mol. Biol. Rep. 5: 387-405.

Johansen, D.A. (1940). Plant Microtechnique. McGraw-Hill Book Co., New York.

John, M.E. and Petersen, M.W. (1994). Cotton (Gossypium hirsutum L.) pollen-specific polygalacturonase m-RNA: tissue and temporal specificity of its promoter in transgenic tobacco. Plant Mol. Biol. 26: 1989-1993.

Koltunow, A.M., Truettner, J., Cox, K.H., Wallroth, M. and Goldberg, R.B. (1990). Different temporal and spatial gene expression patterns occur during anther development. Plant Cell 2: 1201-1224.

Mariani, C., De Beuckeleer, M., Truettner, J., Leemans, J. and Goldberg, R.B. (1990). Induction of male sterility in plants by a chimaeric ribonuclease gene. Nature 347: 737-741.

Mascarenhas, J.P. (1988). Anther- and pollen-expressed genes. In: Temporal and Spatial Regulation of Plant Genes (Verma, D.P.S. and Goldberg, R.B., eds.). Springer-Verlag, New York, pp. 97-115.

Mascarenhas, J.P. (1990). Gene activity during pollen development. Annu. Rev. Plant Physiol. Plant Mol. Biol. 41: 317-338.

McCormick, S. (1991). Molecular analysis of male gametogenesis in plants. Trends Genet. 7: 298-303.

McCormick, S. (1993). Male gametophyte development. Plant Cell 5: 1265-1275.

Morota, H. and Uchimiya, H. (1988). Inheritance and structure of foreign DNA in progenies of transgenic tobacco obtained by direct gene trans- 
fer. Theor. Appl. Genet. 76: 161-164.

Murashige, T. and Skoog, F. (1962). A revised medium for rapid growth and bioassays with tobacco tissue cultures. Physiol. Plant. 15: 473-497.

Nasrallah, J.B., Nishio, T. and Nasrallah, M.E. (1991). The self-incompatibility genes of Brassica: expression and use in genetic ablation of floral tissues. Annu. Rev. Plant Physiol. Plant Mol. Biol. 42: 393-422.

Peach, C. and Velten, J. (1991). Transgene expression variability (position effect) of CAT and GUS reporter genes driven by linked divergent TDNA promoters. Plant Mol. Biol. 17: 49-60.

Roberts, M.R., Boyes, E. and Scott, R.J. (1995). An investigation of the role of the anther tapetum during microspore development using genetic cell ablation. Sex. Plant Reprod. 8: 299-307.

Saas, J.E. (1940). Elements of Botanical Microtechnique. McGraw-Hill, New York.

Schrauwen, J.A.M., de Groot, P.F.M., van Herpen, M.M.A., van der Lee, T.,
Reynen, W.H., Weterings, K.A.P. and Wullems, G.J. (1990). Stagerelated expression of mRNAs during pollen development in lily and tobacco. Planta 182: 298-304.

Scott, R., Hodge, R., Paul, W. and Draper, J. (1991). The molecular biology of anther differentiation. Plant Sci. 80: 167-191.

Trognitz, B.R. (1991). Comparison of different pollen viability assays to evaluate pollen fertility of potato dihaploids. Euphytica 56: 143-148.

Twell, D. (1995). Diphteria toxin-mediated cell ablation in developing pollen: vegetative cell ablation blocks generative cell migration. Protoplasma 187: 144-154.

Zhan, X.Y., Wu, H.M. and Cheung, A.Y. (1996). Nuclear male sterility induced by pollen-specific expression of a ribonuclease. Sex. Plant Reprod. 9: 35-43.

(Received October 27, 1998) 
